\title{
The impact of economic fluctuations on earnings forecast
}

\author{
Ata Molodpoor and Roya Darabi*
}

Department of Accounting, South Tehran Branch, Islamic Azad University, Tehran, Iran

\begin{tabular}{l}
\hline C H R O N I C L E \\
\hline Article history: \\
Received January 25, 2015 \\
Received in revised format 28 \\
March 2015 \\
Accepted 7 May 2015 \\
Available online \\
May 102015 \\
\hline Keywords: \\
Earnings forecast \\
Growth domestic product \\
Tehran Stock Exchange \\
\end{tabular}
\begin{abstract}
A B S T R A C T
Previous studies in the area of earnings forecasts hold a common characteristic, they make no distinction as to the economic cycle when evaluating voluntary earnings disclosures. This paper presents an empirical investigation to study the relationship between actual as well as forecasted earnings and growth domestic product during the economic growth and recession on Tehran Stock Exchange. Using the information of 60 firms over the period of 2007-2012, the study has determined that there was a positive and meaningful relationship between earnings forecast and growth domestic product during economic growth. In addition, the study has determined a meaningful relationship between actual earnings and growth domestic product during the recession.
\end{abstract}

(c) 2015 Growing Science Ltd. All rights reserved.

\section{Introduction}

The 2008-2012 global economic crisis has been recognized as the worst economic crisis since the Great Depression of the 1930s (Haidar, 2012). It was the consequence of total collapse from big financial institutions, the bailout of banks, corporations and downturns in the stock markets anywhere in the world. The real estate market also suffered because of evictions, foreclosures, and prolonged unemployment occurred in the private sector. The crisis played essential role in the failure of important business factors, declines in consumer wealth forecasted in the billions of dollars and a downturn in the economic activity over the period 2008-2012 global recession. There are several studies that, which indicate earnings forecasts could be less beneficial during unsettled economic periods (Miller, 2009). Other literature report that earnings forecasts assist us to cut through the fog of economic uncertainty and are encouraged to help users specifically during such periods (Anilowski et al., 2010). Kuo et al. (2014) studied the earnings management activities in Chinese listed companies and the effect of the split share structure reform (SSSREF). They explained that Chinese listed companies represented a long-term positive relationship between real and accrual-based earnings management activities. This reflects the environment of weak investor protection and insufficient corporate governance in China. Their results also indicates that the SSSREF in China did not fundamentally improved firms' quality of financial information. This could be because ownership concentration remains high. Nevertheless, the

\footnotetext{
* Corresponding author. Tel: +989123194494

E-mail address: royadarabi110@yahoo.com (A. Molodpoor) 
reform created an incentive alignment effect, exogenously. They reported that firms' implementation of discretionary accruals was constrained, and they had consequently shifted to less detectable and under-scrutinized real earnings activities after the reform. Stunda (2013) examined whether voluntary earnings disclosures released during periods of an economic downturn differ from disclosures released during periods of economic expansion. Campello et al. (2010) studied whether corporate spending plans differ conditional on this survey-based measure of financial constraint. They reported that constrained companies planned deeper cuts in tech spending, employment, and capital spending. Constrained companies also burned through more cash, drew more heavily on lines of credit for fear banks would restrict access in the future, and sold more assets to fund their operations. Weeks (2009) investigated the effect of the global financial crisis on the economy of Sierra Leone. Clement et al. (2003) tested the relationship among confirming management forecasts, stock prices, and analyst expectations. They reported that these voluntary disclosures could influence on stock prices and the dispersion of analyst expectations. Specifically, they reported that the market's reaction to confirming forecasts was substantially positive, indicating that benefits accrue to companies that disclose such forecasts. Moreover, although they detected no significant change in the mean consensus forecasts around the confirming forecast date, they reported a significant reduction in the mean and median consensus analyst dispersion. They also reported a positive association between the reduction of dispersion of analysts' forecasts and the magnitude of the stock market response.

\section{The proposed study}

This paper presents an empirical investigation to study the relationship between actual as well as forecasted earnings and growth domestic product during the economic growth and recession on Tehran Stock Exchange. There are several conditions for selection of the firms for this study. First, all firms must be accepted on exchange prior the year of investigation. There must be no change on their fiscal years of financial trade. No financial or holding firm is permitted for this study. All necessary information of the firms must be available. No firm has been deleted or suspended during the period of investigation. Finally, based on the mentioned criteria, 60 firms were selected for the proposed study. In this study, earnings per share (EPS) is dependent variable and growth domestic product (GDP) is dependent variable. In addition, book value of total equities (MOVE) and the ratio of market value (MV) on book value (BV) is considered as independent variables. The proposed study considers the following four regression equations to study the relationship between earnings forecast (EPSP) as well as actual earnings (EPSR) with GDP,

$$
\begin{aligned}
& \mathrm{EPSR}_{\mathrm{i} . \mathrm{t}}=\alpha_{0}+\alpha_{1} \mathrm{GDP}_{\mathrm{i} . \mathrm{t}}+\alpha_{2} \mathrm{MOVE}_{\mathrm{i} . \mathrm{t}}+\alpha_{3} \mathrm{MV} / \mathrm{BV}_{\mathrm{i} . \mathrm{t}}+\varepsilon_{\mathrm{i} . \mathrm{t}} \text {, } \\
& \mathrm{EPSR}_{\mathrm{i} . \mathrm{t}}=\alpha_{0}+\alpha_{1} \mathrm{GDP}_{\mathrm{i} . \mathrm{t}}+\alpha_{2} \mathrm{MOVE}_{\mathrm{i} . \mathrm{t}}+\alpha_{3} \mathrm{MV} / \mathrm{BV}_{\mathrm{i} . \mathrm{t}}+\varepsilon_{\mathrm{i} . \mathrm{t}} \text {, } \\
& \mathrm{EPSP}_{\mathrm{i} . \mathrm{t}}=\alpha_{0}+\alpha_{1} \mathrm{GDP}_{\mathrm{i} . \mathrm{t}}+\alpha_{2} \mathrm{MOVE}_{\mathrm{i} . \mathrm{t}}+\alpha_{3} \mathrm{MV} / \mathrm{BV}_{\mathrm{i} . \mathrm{t}}+\mathcal{E}_{\mathrm{i} . \mathrm{t}} \text {, } \\
& \mathrm{EPSP}_{\mathrm{i} . \mathrm{t}}=\alpha_{0}+\alpha_{1} \mathrm{GDP}_{\mathrm{i} . \mathrm{t}}+\alpha_{2} \mathrm{MOVE}_{\mathrm{i} . \mathrm{t}}+\alpha_{3} \mathrm{MV} / \mathrm{BV}_{\mathrm{i} . \mathrm{t}}+\varepsilon_{\mathrm{i} . \mathrm{t}}
\end{aligned}
$$

First hypothesis: There is relationship between forecasted earnings and GDP during the recession.

Second hypothesis: There is relationship between forecasted earnings and GDP during the economic growth.

Third hypothesis: There is relationship between actual earnings and GDP during the recession.

Fourth hypothesis: There is relationship between actual earnings and GDP during the economic growth. 
The study gathers the necessary information of 60 selected firms from 2007 to 2012 to investigate the relationship between dependent variable and independent variables. Table 1 and Table 2 demonstrate the information of some basic information.

Table 1

The summary of some basic statistics for actual earnings

\begin{tabular}{lccccc}
\hline Variable & Mean & Median & Max & Min & Std. dev. \\
\hline Actual earnings & 0.003 & 0.001 & 0.057 & -0.016 & 0.007 \\
GDP & 12.143 & 6.904 & 96.26 & 0.393 & 14.396 \\
MOVE & 9.251 & 0.907 & 466.11 & 0.011 & 32.02 \\
MV/BV & 5.573 & 2.392 & 802.36 & 0.001 & 42.37 \\
\hline
\end{tabular}

Table 2

The summary of some basic statistics for forecasted earnings

\begin{tabular}{lccccc}
\hline Variable & Mean & Median & Max & Min & Std. dev. \\
\hline Actual earnings & 0.004 & 0.0014 & 0.037 & -0.0007 & 0.006 \\
GDP & 12.143 & 6.904 & 96.26 & 0.393 & 14.396 \\
MOVE & 9.251 & 0.907 & 466.11 & 0.011 & 32.02 \\
MV/BV & 5.573 & 2.392 & 802.36 & 0.001 & 42.37 \\
\hline
\end{tabular}

In addition, the implementation of Kolmogorov-Smirnov test for actual and forecasted earnings yields $\mathrm{z}=0.091$ (Sig. $=0.000)$ and $\mathrm{z}=0.090$ (Sig. $=0.000)$, respectively, which means the data were not normally distributed. Therefore we used Johnson Transformation and Box-Cox (Box \& Cox, 1964) to normalize the data. The implementation of Kolmogorov-Smirnov test for actual and forecasted earnings after transformation yields $\mathrm{z}=0.041$ (Sig. $=0.077$ ) and $\mathrm{z}=0.045$ (Sig. $=0.091$ ), respectively. Table 3 shows the results of correlation among different pairs of variables.

Table 3

The summary of correlation test for actual earnings

\begin{tabular}{|c|c|c|c|c|}
\hline Variable & Actual earnings & GDP & MOVE & $\mathrm{MV} / \mathrm{BV}$ \\
\hline Actual earnings & 1 & & & \\
\hline GDP & $-0.696^{* *}$ & 1 & & \\
\hline MOVE & 0.279 & $0.236^{* *}$ & 1 & \\
\hline $\mathrm{MV} / \mathrm{BV}$ & $0.010^{*}$ & -0.022 & 0.086 & 1 \\
\hline
\end{tabular}

\section{Table 4}

The summary of correlation test for forecasted earnings

\begin{tabular}{lcccc}
\hline Variable & Actual earnings & GDP & MOVE & MV/BV \\
\hline Actual earnings & 1 & & & \\
GDP & $-0.696^{* *}$ & 1 & 1 & 1 \\
MOVE & $0.307^{* *}$ & $0.236^{* *}$ & 0.086 & \\
MV/BV & -0.004 & -0.022 & &
\end{tabular}

According to the results of Table 3 and Table 4, there are not strong correlation between independent variables. In order to perform regression analysis, we need to select between fixed/random effect as well as panel data. This is accomplished using F-Limer and Hausman tests and Table 5 demonstrates the results of our survey.

\section{Table 5}

The summary of F-Limer and Hausman tests for Eq. (1) to Eq. (4)

\begin{tabular}{lccl}
\hline Model & F-Limer(Sig.) & Hausman (Sig.) & Result \\
\hline Eq. (1) & $1.397(0.006)$ & $33.347(0.000)$ & Panel method with fixed effect \\
Eq. (2) & $3.49(0.000)$ & $1.09(0.779)$ & Panel method with random effect \\
Eq. (3) & $3.635(0.000)$ & $40.934(0.000)$ & Panel method with fixed effect \\
Eq. (4) & $3.21(0.000)$ & $1.92(0.588)$ & Panel method with random effect \\
\hline
\end{tabular}




\section{The results}

In this section, we present the results of the implementation of regression techniques on testing various hypotheses of the survey.

\subsection{The first hypothesis: Relationship between GDP and forecasted earnings during recession}

The first hypothesis of the survey is associated with the relationship between GDP and forecasted earnings during the recession time. Table 6 shows details of our findings.

\section{Table 6}

The summary of regression between GDP and forecasted earnings during the recession

\begin{tabular}{lccc}
\hline Variable & Coefficient & t-value & Standard error \\
\hline Intercept & 0.001 & 0.146 & 0.884 \\
GDP & 0.003 & 6.435 & 0.000 \\
MOVE & -0.004 & -2.146 & 0.033 \\
MV/BV & 0.003 & 2.632 & 0.009 \\
\hline
\end{tabular}

$\mathrm{R}^{2}=0.79$, Adjusted $\mathrm{R}^{2}=0.68$ F-value $=7.33(0.000)$ Durbin-Watson $=2.27$

According to the results of Table 6, all t-student values associated with GDP, MOVE and MV/BV are meaningful when the level of significance is five percent. Adjusted R-Square is equal to 0.68, which means the independent variables could describe approximately 68 percent of the changes on dependent variable. Moreover, F-value is equal 7.33 with Sig. $=0.000$, which indicates that the relationship between independent variable and dependent variable was linear. In addition, Durbin-Watson value is equal to 2.27, which means there was no auto-correlation among residuals. The positive coefficient between GDP and forecasted earning indicates that there was a positive relationship between these two variables, which confirm the hypothesis.

\subsection{The second hypothesis: Relationship between GDP and forecasted earnings during economic growth}

The second hypothesis of the survey is associated with the relationship between GDP and forecasted earnings during the economic growth. Table 7 presents details of our findings.

\section{Table 7}

The summary of regression between GDP and forecasted earnings during the economic growth

\begin{tabular}{lccc}
\hline Variable & Coefficient & t-value & Standard error \\
\hline Intercept & -0.006 & -0.714 & 0.476 \\
GDP & 0.0002 & 8.256 & 0.000 \\
MOVE & 0.0007 & 0.289 & 0.772 \\
MV/BV & 0.0002 & 0.374 & 0.708 \\
\hline
\end{tabular}

$\mathrm{R}^{2}=0.30$, Adjusted $\mathrm{R}^{2}=0.29$ F-value $=25.98(0.000)$ Durbin-Watson $=1.97$

According to the results of Table 7, the t-student value associated with actual earnings is meaningful when the level of significance is five percent. Adjusted R-Square is equal to 0.29, which means the independent variables could describe approximately 29 percent of the changes on dependent variable. Moreover, F-value is equal 25.98 with Sig. $=0.000$, which indicates that the relationship between independent variable and dependent variable was linear. In addition, Durbin-Watson value is equal to 1.97, which means there was no auto-correlation among residuals. The positive coefficient between GDP and forecasted earning indicates that there was a positive relationship between these two variables, which confirm the hypothesis. 


\subsection{The third hypothesis: Relationship between GDP and actual earnings during recession}

The third hypothesis of the survey is associated with the relationship between GDP and actual earnings during the recession time. Table 8 presents details of our results.

\section{Table 8}

The summary of regression between GDP and actual earnings during the recession

\begin{tabular}{lccc}
\hline Variable & Coefficient & t-value & Standard error \\
\hline Intercept & 0.001 & 3.516 & 0.0006 \\
GDP & 0.0002 & 8.606 & 0.000 \\
MOVE & 0.0001 & 1.212 & 0.227 \\
MV/BV & -0.0008 & -0.988 & 0.325 \\
\hline
\end{tabular}

$\mathrm{R}^{2}=0.89$, Adjusted $\mathrm{R}^{2}=0.83$ F-value $=15.65(0.000)$ Durbin-Watson $=2.19$

According to the results of Table 8, all t-student values associated with GDP, MOVE and MV/BV are meaningful when the level of significance is five percent. Adjusted R-Square is equal to 0.83, which means the independent variables could describe approximately 83 percent of the changes on dependent variable. Moreover, F-value is equal 15.65 with Sig. $=0.000$, which indicates that the relationship between independent variable and dependent variable was linear. In addition, Durbin-Watson value is equal to 2.19, which means there was no auto-correlation among residuals. The positive coefficient between GDP and actual earning indicates that there was a positive relationship between these two variables, which confirm the hypothesis.

\subsection{The fourth hypothesis: Relationship between GDP and actual earnings during economic growth}

The last hypothesis of the survey is associated with the relationship between GDP and actual earnings during the economic growth. Table 8 presents details of our findings.

\section{Table 9}

The summary of regression between GDP and actual earnings during the economic growth

\begin{tabular}{lccc}
\hline Variable & Coefficient & t-value & Standard error \\
\hline Intercept & 0.005 & 0.092 & 0.926 \\
GDP & 0.0002 & 11.765 & 0.000 \\
MOVE & -0.0002 & -1.630 & 0.104 \\
MV/BV & -0.0005 & -0.103 & 0.917 \\
\hline
\end{tabular}

$\mathrm{R}^{2}=0.45$, Adjusted $\mathrm{R}^{2}=0.44$ F-value $=48.02(0.000)$ Durbin-Watson $=1.71$

According to the results of Table 9, the t-student value associated with actual earnings is meaningful when the level of significance is five percent. Adjusted R-Square is equal to 0.44, which indicates the independent variables could describe approximately 44 percent of the changes on dependent variable. Moreover, F-value is equal 48.02 with Sig. $=0.000$, which indicates that the relationship between independent variable and dependent variable was linear. In addition, Durbin-Watson value is equal to 1.71, which means there was no auto-correlation among residuals. The positive coefficient between GDP and actual earning indicates that there was a positive relationship between these two variables, which confirm the hypothesis.

\section{Conclusion}

In this paper, we have presented a survey one relationship between GDP and earning forecast/actual earnings for selected firms listed on Tehran Stock Exchange. Using some regression techniques, the study has detected some positive and meaningful relationships between earnings forecast as well as actual earnings and growth domestic product. The results of this study are consistent with findings earlier reported in the literature (Campello et al., 2010; Kuo et al., 2014). 


\section{Acknowledgement}

The authors would like to thank the anonymous referees for constructive comment on earlier version of this paper.

\section{References}

Anilowski, C., M. Feng, \& D. Skinner (2010). Does earnings guidance affect market returns?. The Journal of Accounting and Economics, (44), 36-63.

Box, G. E., \& Cox, D. R. (1964). An analysis of transformations. Journal of the Royal Statistical Society. Series B (Methodological), 211-252.

Campello, M., Graham, J. R., \& Harvey, C. R. (2010). The real effects of financial constraints: Evidence from a financial crisis. Journal of Financial Economics, 97(3), 470-487.

Clement, M., Frankel, R., \& Miller, J. (2003). Confirming management earnings forecasts, earnings uncertainty, and stock returns. Journal of Accounting Research, 41(4), 653-679.

Haidar, J. I. (2012). Sovereign credit risk in the euro zone. World Economics,13(1), 123-136.

Kuo, J. M., Ning, L., \& Song, X. (2014). The real and accrual-based earnings management behaviors: Evidence from the split share structure reform in China. The International Journal of Accounting, 49(1), 101-136.

Miller, G. (2009). Should managers provide forecasts of earnings? Journal of Accounting Research, 40(1), 173-204.

Stunda, R. A. (2013). The impact of economic fluctuations on earnings forecasts. Global Journal of Business Research, 5(2), 55-64.

Weeks, J. (2009). The impact of the global financial crisis on the economy of Sierra Leone. International Policy Centre for Inclusive Growth, 18, 138-152. 